Fourth International Conference on Sustainable Construction Materials and Technologies http://www.claisse.info/Proceedings.htm

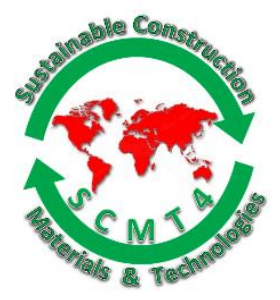

SCMT4

Las Vegas, USA, August 7-11, 2016

\title{
Study of Concrete Properties with High Alumina Blast Furnace Slag
}

\author{
Shohei Kimura ${ }^{1 a}$, Yoshihito Kuroiwa ${ }^{1 b}$, and Hideaki Nakayama ${ }^{1 \mathrm{c}}$ \\ ${ }^{I}$ Mitsubishi Materials Corporation, 2270 Yokose, Yokose-cho, Chichibu-gun Saitama Pref. 368-8504 \\ Japan.

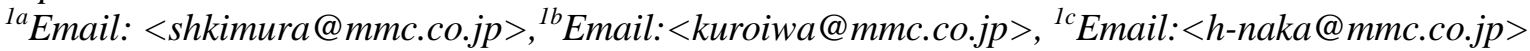

\begin{abstract}
Cement production consumes much fossil fuel and electricity emitting a large amount of carbon dioxide during burning processes. Reduction of the amount of clinker directly decreases carbon dioxide emission. Partial replacement of Portland cement with an admixture is an effective method in decreasing the amount of clinker and carbon dioxide. Use of ground granulated blast furnace slag effectively reduces the amount of carbon dioxide emission derived from the binder of concrete. However, there are few steel plants in the western US. Therefore, ground granulated blast furnace slag powder for use in this area should be imported from East Asia, including Japan. Because ground granulated blast furnace slag powder produced in Japan contains larger amount of alumina than that produced in the United States, the concrete properties may differ from the conventional results obtained in the United States. This study investigated properties of concrete produced with ground granulated blast furnace slag powder contains high amounts of alumina. As a result, the resistance to sulfate attack and length change were equal to those of non-slag concrete. However, the resistance to carbonation was slightly low. Also, replacement with the ground granulated blast furnace slag improved the chloride ion permeability. These results suggest that ground granulated blast furnace slag powder produced in Japan could be used as an admixture of concrete for United States.
\end{abstract}

\section{INTRODUCTION}

The ground granulated blast furnace slag (GGBFS) is used as an admixture of concrete and expected to improve long term strength and durability including chloride ion permeability and resistance against chemical attacks. Moreover, partial replacement of cement with GGBFS can reduce carbon dioxide emission of concrete because replacement with GGBFS reduces the amount of clinker in cement or concrete. Fly ash (FA) and natural pozzolana are widely used in western of U.S, while usage records of GGBFS as a concrete admixture is few. This may be attributed to that western area of U.S. do not have steel plants.

On the other hand, Assembly Bill32 (AB32) has been enforced in California State requiring to reduce Green House Gases including carbon dioxide emissions down to 1990 levels by 2020 [EPA.gov]. It is considered that use of GGBFS is a helpful way of reducing carbon dioxide within construction industry. When GGBFS is used in western U.S, GGBFS shall be transported from eastern U.S. or imported from East Asia including Japan. The GGBFS produced in Japan has high alumina content compared to those produced in U.S. Therefore, concrete properties using GGBFS may differ from the past results studied in U.S. Moreover, the concrete is required to be highly resistant to sulfate attack in western area of U.S. where soils are rich in hydrosulfate. In this study, concrete properties using high alumina GGBFS are investigated and discussed on the applicability of Japanese GGBFS to U.S. 


\section{EXPRIMENTAL PROCEDURE}

Materials. The materials used are shown in Table 1, and chemical composition of the materials used are shown in Table 2. Based cement was Type V widely used in California. Ground granulated blast furnace slag (GGBFS) was produced in Japan containing $14.67 \%$ of $\mathrm{Al}_{2} \mathrm{O}_{3}$. Fly ash (FA) was produced in Arizona State. Gypsum with a median diameter of $10 \mu \mathrm{m}$ was previously added to GGBFS for $3.0 \%$ equivalent to the $\mathrm{SO}_{3}$ content of GGBFS. Expansion of concrete due to sulfate attack is attributed to ettringite formation, where monosulfate in the concrete is transformed to ettringite by external sulfate ions. Ettringite is not transformed to the monosulfate at early hydration when gypsum is previously added to the GGBFS [Arai 1984]. Therefore, concrete expansion due to sulfates attack as described above does not occur and improvement of sulfate resistance can be expected. The activity index of GGBFS is shown in Table 3 and the activity index of the FA is shown in Table 4. GGBFS corresponds to Grade100 of ASTM C 989 and FA can be applicable as Class F in ASTM C618. Aggregate was manufactured in Lurcern Valley (fine aggregate: S1, coarse aggregate: G1).

Table 1. Materials

\begin{tabular}{|c|c|c|c|}
\hline Material & Type & Symbol & Details \\
\hline Cement & Portland Cement Type V & Type V & Density:3.16g/cm ${ }^{3}$ \\
\hline \multirow{2}{*}{ Admixture } & Blast furnace slag & GGBFS & Produced in Japan \\
\cline { 2 - 4 } & Fly ash & FA & Arizona State, Class F \\
\hline Gypsum & Reagent gypsum & Gy & Median diameter $10 \mu \mathrm{m}$ \\
\hline Fine agg. & Sand & S1 & Lurcern Valley \\
\hline Coarse agg. & Nominal Size 3/8" & G1 & Lurcern Valley \\
& Nominal Size 1" & & Combined ratio $3 / 8 ": 1 "=2: 8$ \\
\hline Chemical admixture & Water-Reducing Agent & Ad & Type A \\
\hline
\end{tabular}

Table 2. Chemical Composition of Cement and Admixtures (unit:\%)

\begin{tabular}{|c|c|c|c|c|c|c|c|c|c|c|c|c|c|c|c|}
\hline & ig.loss & $\mathrm{SiO}_{2}$ & $\mathrm{Al}_{2} \mathrm{O}_{3}$ & $\mathrm{Fe}_{2} \mathrm{O}_{3}$ & $\mathrm{CaO}$ & $\mathrm{MgO}$ & $\mathrm{S}$ & $\mathrm{SO}_{3}$ & $\mathrm{Na}_{2} \mathrm{O}$ & $\mathrm{K}_{2} \mathrm{O}$ & $\mathrm{TiO}_{2}$ & $\mathrm{P}_{2} \mathrm{O}_{5}$ & $\mathrm{MnO}$ & $\mathrm{SrO}$ & $\mathrm{Total}$ \\
\hline Type V & 1.62 & 21.00 & 3.66 & 3.67 & 63.43 & 2.66 & - & 2.52 & 0.12 & 0.71 & 0.20 & 0.14 & 0.05 & 0.12 & 99.90 \\
\hline GGBFS & 0.20 & 34.10 & 14.67 & 0.25 & 41.50 & 7.20 & 0.93 & 0.02 & 0.19 & 0.33 & 0.54 & - & 0.32 & - & 99.32 \\
\hline FA & 2.57 & 60.83 & 22.95 & 4.55 & 5.25 & 1.08 & - & 0.33 & 0.38 & 1.17 & 1.25 & 0.61 & 0.05 & - & 101.01 \\
\hline
\end{tabular}

Table 3. GGBFS Activity Index and Grade by ASTM C989

\begin{tabular}{|c|c|c|c|c|}
\hline \multirow{2}{*}{ Age } & \multirow{2}{*}{ Activity index } & \multicolumn{3}{|c|}{ ASTM C989 Grade } \\
\cline { 3 - 5 } & & Grade 80 & Grade 100 & Grade 120 \\
\hline 7days & 79 & - & $\geqq 75$ & $\geqq 115$ \\
\hline 28days & 127 & $\geqq 75$ & $\geqq 95$ & \\
\hline
\end{tabular}

Table 4. Fly Ash Activity Index by ASTM C618

\begin{tabular}{|c|c|c|}
\hline Age & Activity index & ASTM C608 Requirements \\
\hline 7 days & 84 & $\geqq 75$ \\
\hline 28days & 94 & $\geqq 75$ \\
\hline
\end{tabular}

Test Procedure. In this study, fresh properties, strength properties and durability including sulfate resistance, carbonation speed, chloride permeability and drying shrinkage were measured. The concrete test items and methods are shown in Table 5. 
Table 5. Concrete Test Items and Test Methods

\begin{tabular}{|c|c|c|c|}
\hline \multicolumn{2}{|c|}{ Measuring Specification } & Test Method & Note \\
\hline \multirow[t]{2}{*}{ Fresh properties } & Slump & ASTM C143/C143M & \\
\hline & Air content & ASTM C231 & \\
\hline \multirow[t]{2}{*}{ Mechanical properties } & $\begin{array}{l}\text { Compressive } \\
\text { strength }\end{array}$ & ASTM C39/C39M & $\begin{array}{l}\text { Cured by ASTM C31/C } 31 \mathrm{M} \\
\text { Test ages: } 3,7,28,56 \text { and 91days. }\end{array}$ \\
\hline & Elastic modulus & ASTM C469/C469M & \\
\hline \multirow[t]{4}{*}{ Durability } & Sulfate resistance & JSTM C7401:1999 & $\begin{array}{l}\text { Japan Testing Center for } \\
\text { Construction Materials Method }\end{array}$ \\
\hline & $\begin{array}{l}\text { Carbonation } \\
\text { resistance } \\
\end{array}$ & JIS A 1153 & \\
\hline & $\begin{array}{c}\text { Chloride } \\
\text { Permeability }\end{array}$ & ASTM C1202 & Rapid method \\
\hline & Drying shrinkage & ASTM C157 & $\begin{array}{l}\text { Exposure conditions } \\
\text { - Temperature: } 23{ }^{\circ} \mathrm{C} \\
\text { - Relative Humidity: } 50 \%\end{array}$ \\
\hline
\end{tabular}

\section{RESULTS AND DISCUSSION}

Concrete Mix Proportion. Mix proportions of the control concrete are shown in Table 6. The nominal strength of the control concrete were 21,28 and $35 \mathrm{~N} / \mathrm{mm}^{2}$ and water-cement ratios were 60,49 and $40 \%$ determined with reference to the concrete mix proportion of a ready-mix concrete plant in California State. The control concrete with a W/C of $49 \%$ contains FA. GGBFS replacement levels were 20,40 and $50 \%$. The water-binder ratios to obtain equal strength to the control concrete were determined according to the preliminary tests. Mix proportions of concrete tested are shown in Table 7.

Table 6. Mix Proportions of Control Concrete

\begin{tabular}{|c|c|c|c|c|c|c|c|c|}
\hline \multirow{3}{*}{$\begin{array}{l}\mathrm{W} / \mathrm{C} \\
(\%)\end{array}$} & \multirow{3}{*}{$\begin{array}{l}\text { Air } \\
(\%)\end{array}$} & \multirow{3}{*}{$\begin{array}{c}\text { Slump } \\
(\mathrm{cm})\end{array}$} & \multicolumn{5}{|c|}{ Unit Weight $\left(\mathrm{kg} / \mathrm{m}^{3}\right)$} & \multirow{3}{*}{$\begin{array}{l}\text { Nominal } \\
\text { Strength } \\
\left(\mathrm{N} / \mathrm{mm}^{2}\right)\end{array}$} \\
\hline & & & \multirow[t]{2}{*}{ W } & \multicolumn{2}{|c|}{ Cement } & \multirow[t]{2}{*}{$\mathrm{S}$} & \multirow[t]{2}{*}{ G } & \\
\hline & & & & TypeV & FA & & & \\
\hline 60 & \multirow[t]{3}{*}{3.0} & \multirow[t]{3}{*}{$10 \pm 2.5$} & 177 & 295 & - & 852 & 980 & 21 \\
\hline 49 & & & 176 & 306 & 54 & 803 & 962 & 28 \\
\hline 40 & & & 172 & 430 & - & 801 & 962 & 35 \\
\hline
\end{tabular}

Table 7. Mix Proportions of Concrete for Durability Tests

\begin{tabular}{|c|c|c|c|c|c|c|c|c|c|c|}
\hline \multirow{3}{*}{$\begin{array}{c}\text { Replacement } \\
\text { level of } \\
\text { GGBFS }(\%)\end{array}$} & \multirow{3}{*}{$\begin{array}{l}\text { Nominal } \\
\text { Strength } \\
\left(\mathrm{N} / \mathrm{mm}^{2}\right)\end{array}$} & \multirow{3}{*}{$\begin{array}{l}\text { W/B } \\
(\%)\end{array}$} & \multirow{3}{*}{$\begin{array}{c}\mathrm{s} / \mathrm{a} \\
(\%)\end{array}$} & \multicolumn{6}{|c|}{ Unit weight $\left(\mathrm{kg} / \mathrm{m}^{3}\right)$} & \multirow{3}{*}{$\begin{array}{l}\text { Ad } \\
(\mathrm{B} \\
\times \%)\end{array}$} \\
\hline & & & & \multirow[t]{2}{*}{$\mathrm{W}$} & \multicolumn{3}{|c|}{ Binder } & \multirow[t]{2}{*}{$\mathrm{S} 1$} & \multirow[t]{2}{*}{ G1 } & \\
\hline & & & & & Type V & $\begin{array}{c}\text { GG } \\
\text { BFS }\end{array}$ & FA & & & \\
\hline 0 & \multirow[t]{4}{*}{21} & 60 & \multirow[t]{4}{*}{45} & 174 & 290 & 0 & 0 & 802 & 1041 & \multirow[t]{8}{*}{0.20} \\
\hline 20 & & 63 & & 174 & 301 & 53 & 0 & 806 & 1046 & \\
\hline 40 & & 62 & & 174 & 159 & 106 & 0 & 801 & 1033 & \\
\hline 55 & & 62 & & 174 & 127 & 155 & 0 & 802 & 1041 & \\
\hline 0 & \multirow[t]{4}{*}{28} & 49 & \multirow[t]{4}{*}{44} & 173 & 301 & 0 & 53 & 774 & 1004 & \\
\hline 20 & & 55 & & 176 & 256 & 64 & 0 & 787 & 1022 & \\
\hline 40 & & 54 & & 176 & 189 & 129 & 0 & 787 & 1022 & \\
\hline 55 & & 54 & & 176 & 147 & 180 & 0 & 782 & 1015 & \\
\hline 0 & \multirow[t]{4}{*}{35} & 40 & \multirow[t]{4}{*}{40} & 175 & 438 & 0 & 0 & 680 & 1041 & \multirow[t]{4}{*}{0.35} \\
\hline 20 & & 42 & & 175 & 334 & 84 & 0 & 685 & 1048 & \\
\hline 40 & & 41 & & 175 & 257 & 171 & 0 & 680 & 1041 & \\
\hline 55 & & 41 & & 175 & 193 & 235 & 0 & 679 & 1038 & \\
\hline
\end{tabular}

Air : $3.0 \pm 1.0 \%$, Slump : $10 \pm 2.5 \mathrm{~cm}$ 
Compressive Strength. Compressive strength of concretes with different GGBFS content are shown in Fig. 2 where that of the control concrete was confirmed to be almost equal to others at 28 days. However, when the replacement level of GGBFS increases, the 7-day compressive strength decreases slightly compared to that of the control concrete.
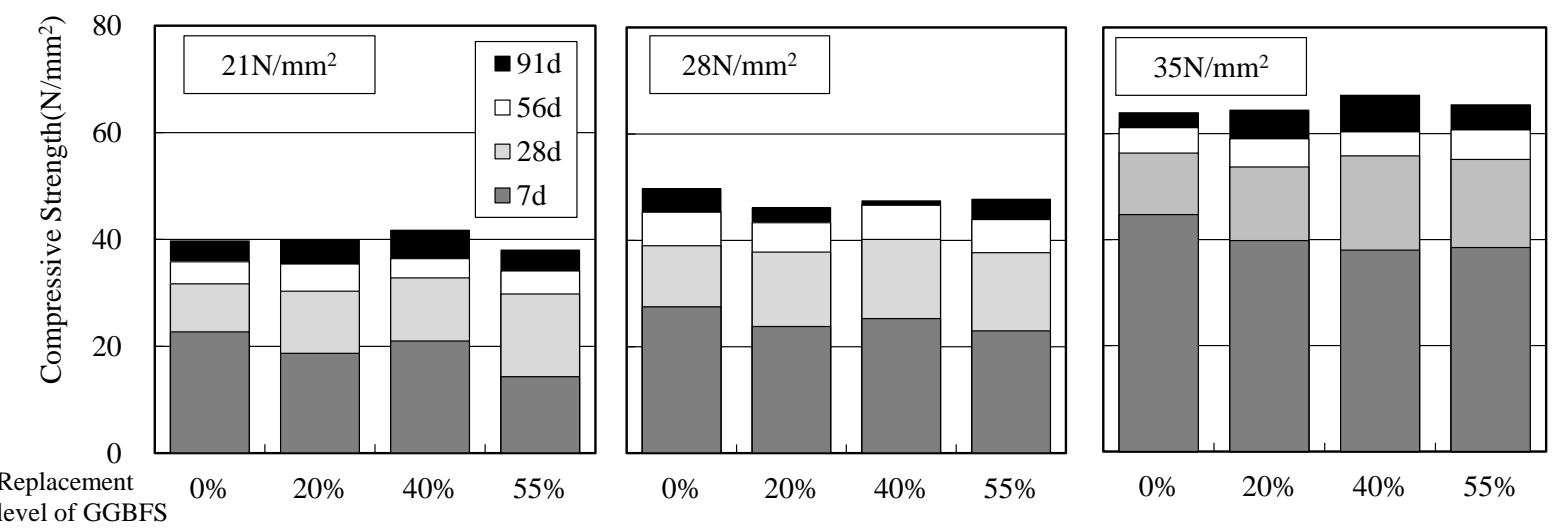

Figure 2. Compressive Strength of Concrete

Sulfate Resistance Changes in expansion strains of concrete submerged in sulfate sodium solution (10 wt $\%-\mathrm{NaSO}_{4}$ ) are shown in Fig. 3. Slight sulfate expansion was found for all specimens. The picture of specimens after 52 weeks submerged in sulfate sodium solution are shown in Fig. 4 to 6. No crack or deficit of specimens were confirmed.
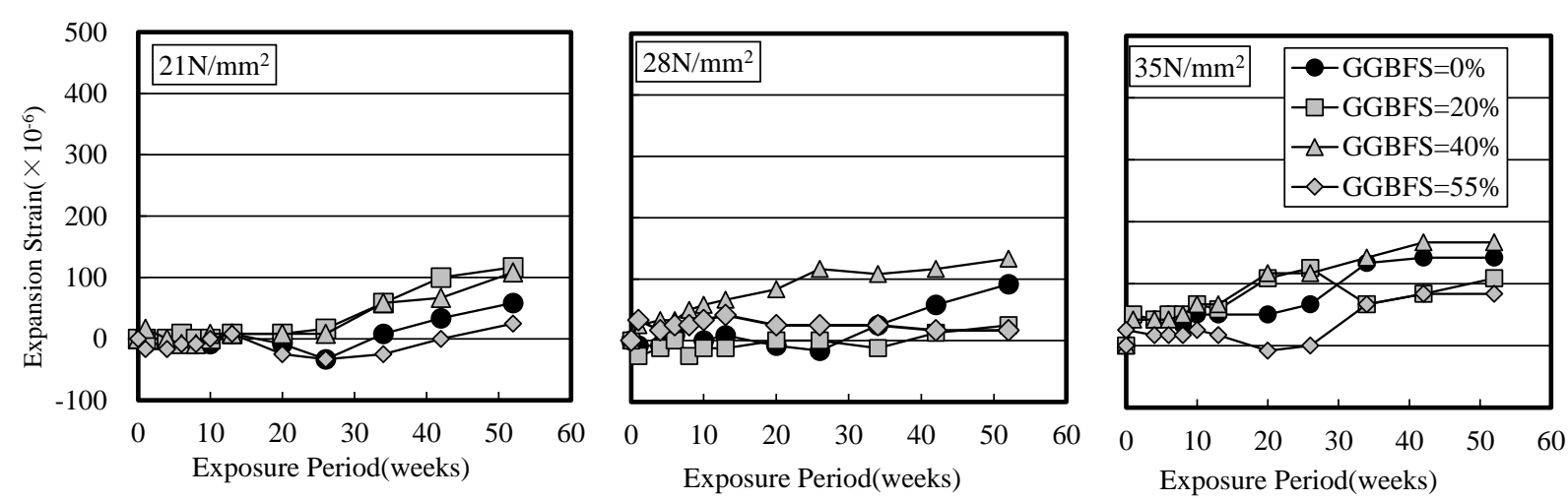

Figure 3. Sulfate Expansion Strain of Concrete

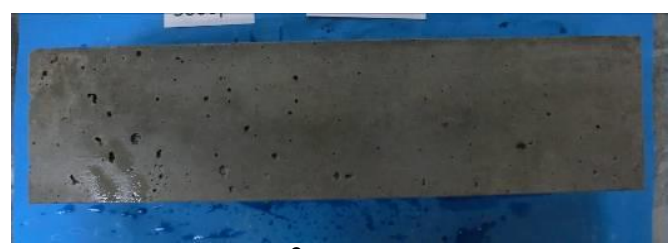

$21 \mathrm{~N} / \mathrm{mm}^{2}, \mathrm{GGBFS}=0 \%$

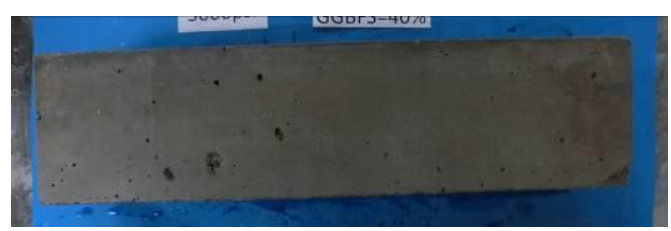

$21 \mathrm{~N} / \mathrm{mm}^{2}, \mathrm{GGBFS}=40 \%$

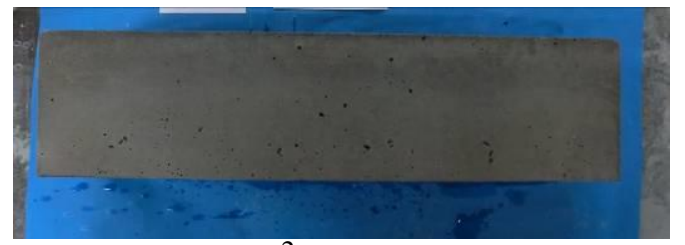

$21 \mathrm{~N} / \mathrm{mm}^{2}, \mathrm{GGBFS}=20 \%$

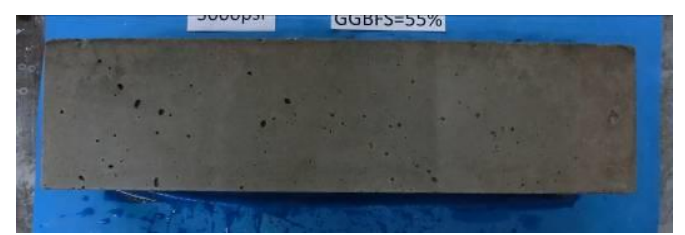

$21 \mathrm{~N} / \mathrm{mm}^{2}, \mathrm{GGBFS}=50 \%$

Figure 4. Appearance of Concrete Specimens Submerged in Sulfate Solution $\left(21 \mathrm{~N} / \mathrm{mm}^{2}\right)$ 


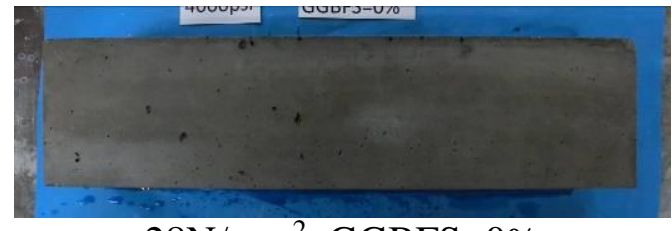

$28 \mathrm{~N} / \mathrm{mm}^{2}, \mathrm{GGBFS}=0 \%$

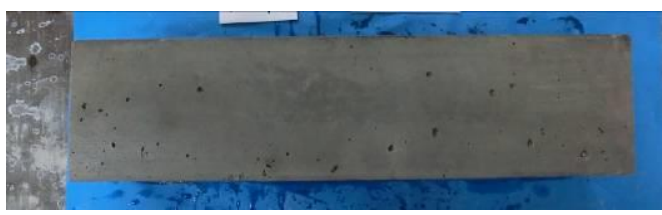

$28 \mathrm{~N} / \mathrm{mm}^{2}, \mathrm{GGBFS}=40 \%$

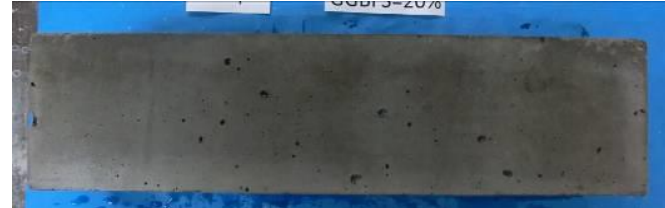

$28 \mathrm{~N} / \mathrm{mm}^{2}, \mathrm{GGBFS}=20 \%$

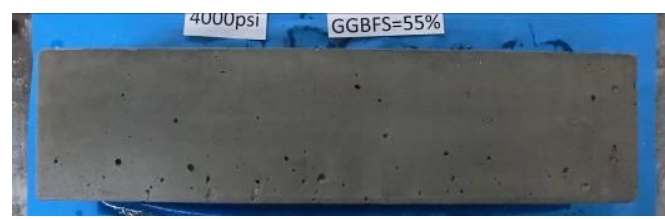

$28 \mathrm{~N} / \mathrm{mm}^{2}, \mathrm{GGBFS}=55 \%$

Figure 5. Appearance of Concrete Specimens Submerged in Sulfate Solution $\left(28 \mathrm{~N} / \mathrm{mm}^{2}\right)$

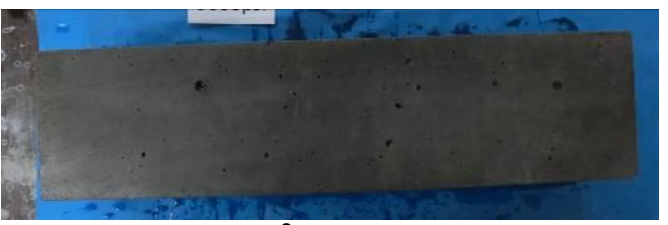

$35 \mathrm{~N} / \mathrm{mm}^{2}, \mathrm{GGBFS}=0 \%$

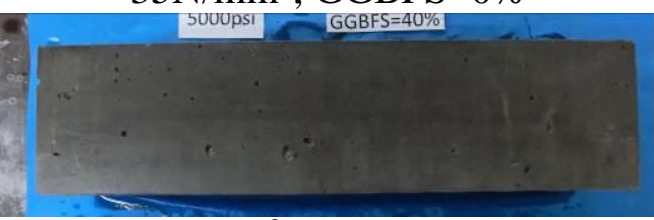

$35 \mathrm{~N} / \mathrm{mm}^{2}, \mathrm{GGBFS}=40 \%$

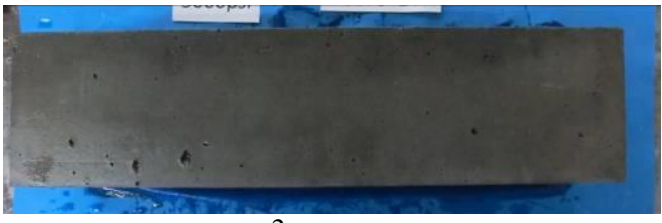

$35 \mathrm{~N} / \mathrm{mm}^{2}, \mathrm{GGBFS}=20 \%$

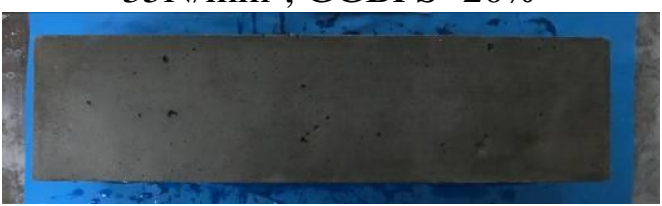

$35 \mathrm{~N} / \mathrm{mm}^{2}, \mathrm{GGBFS}=55 \%$

Figure 6. Appearance of Concrete Specimens Submerged in Sulfate Solution $\left(35 \mathrm{~N} / \mathrm{mm}^{2}\right)$

Accelerated Carbonation Depth. Results of the accelerated carbonation test of concrete are shown in Fig. 7. The carbonation speed indexes are shown in Table 8. Carbonation speed of specimen with GGBFS was faster than control specimen. Replacement of Portland cement with GGBFS generically increase carbonation speed of concrete and the results of carbonation test in this study follow this tendency.
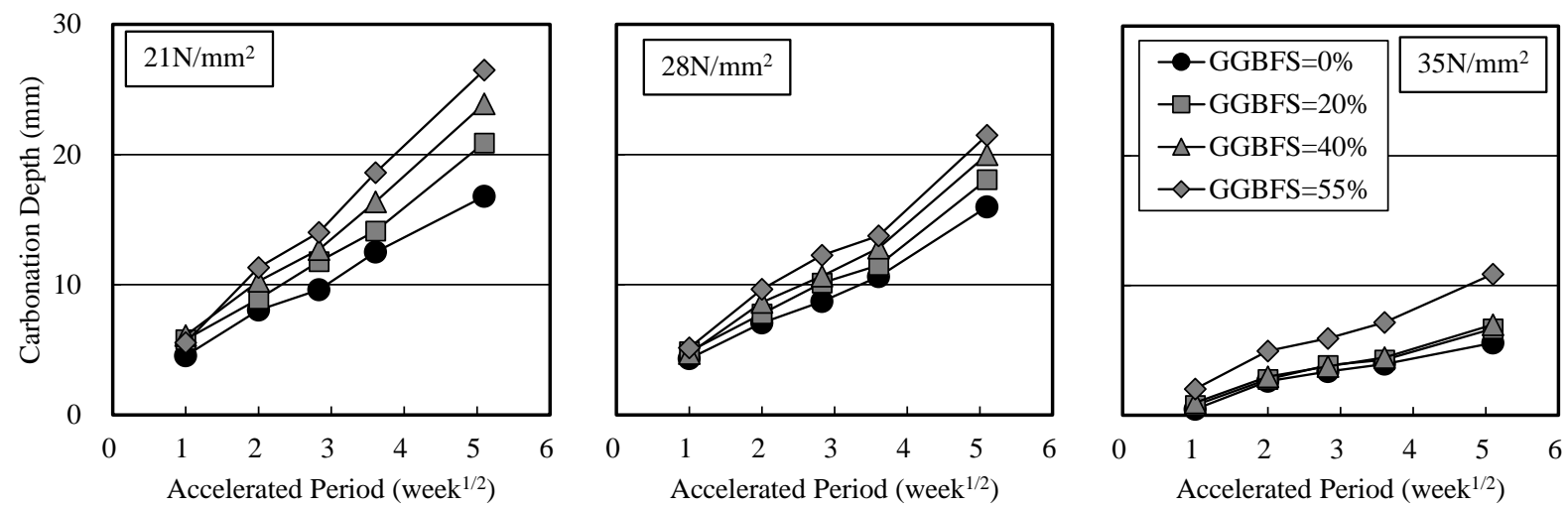

Figure 7. Carbonation Depth of Concrete 
Table 8. Carbonation Speed Index of Concrete

\begin{tabular}{|c|c|c|c|}
\hline $\begin{array}{l}\text { Nominal Strength } \\
\qquad\left(\mathrm{N} / \mathrm{mm}^{2}\right)\end{array}$ & $\begin{array}{c}\text { Replacement Level of GGBFS } \\
\qquad(\%)\end{array}$ & $\begin{array}{l}\mathrm{W} / \mathrm{B} \\
(\%)\end{array}$ & $\begin{array}{c}\text { Carbonation Speed Index } \\
\qquad\left(\mathrm{mm} / \text { weeks }^{1 / 2}\right)\end{array}$ \\
\hline \multirow[t]{4}{*}{21} & 0 & 60 & 3.8 \\
\hline & 20 & 63 & 4.4 \\
\hline & 40 & 62 & 4.8 \\
\hline & 55 & 62 & 5.2 \\
\hline \multirow[t]{4}{*}{28} & $0(\mathrm{FA}=15 \%)$ & 49 & 3.3 \\
\hline & 20 & 55 & 3.9 \\
\hline & 40 & 54 & 4.2 \\
\hline & 55 & 54 & 4.6 \\
\hline \multirow[t]{4}{*}{35} & 0 & 40 & 1.4 \\
\hline & 20 & 42 & 1.4 \\
\hline & 40 & 41 & 1.5 \\
\hline & 55 & 41 & 2.3 \\
\hline
\end{tabular}

Chloride Ion Permeability. According to ASTM C 1202, chloride ion permeability of concrete is evaluated by the amount of charge passed through the specimen. The chloride ion permeability of concrete is classified by category as shown in Table 9. The results of charge passed and chloride ion permeability categorized by ASTM C 1202 of each concrete are shown in Table 10. The resistance to penetration of chloride ion in concrete was improved by GGBFS replacement. Because the amount of $\mathrm{C}_{3} \mathrm{~A}$ capable of fixing chloride ion as Friedel's salt is small in sulfate-resistance Portland cement, the chloride ion permeability of concrete using Type $\mathrm{V}$ would be higher than using other types Portland cement [Yeau and Kim 2005]. These results indicate that the GGBFS suppresses the high permeability of concrete with Type V.

Table 9. Chloride Ion Permeability Based on Charge Passed

\begin{tabular}{|c|c|}
\hline Charge Passed (coulombs) & Chloride Ion Permeability \\
\hline$>4000$ & High \\
\hline $2000-4000$ & Loderate \\
\hline $1000-2000$ & Very Low \\
\hline $100-1000$ & Negligible \\
\hline$<100$ & Low \\
\hline
\end{tabular}


Table 10. Charge Passed of GGBFS Concrete and Classes

\begin{tabular}{|c|c|c|c|c|}
\hline $\begin{array}{c}\text { Nominal Strength } \\
(\mathrm{psi})\end{array}$ & $\begin{array}{c}\text { Replacement Level of } \\
\text { GGBFS } \\
(\%)\end{array}$ & $\begin{array}{c}\text { W/B } \\
(\%)\end{array}$ & $\begin{array}{c}\text { Charge Passed } \\
(\text { Coulomb })\end{array}$ & $\begin{array}{c}\text { Chloride Ion } \\
\text { Permeability }\end{array}$ \\
\hline \multirow{3}{*}{3000} & 0 & 60 & 5030 & High \\
\cline { 2 - 5 } & 20 & 63 & 2860 & Moderate \\
\cline { 2 - 5 } & 40 & 62 & 2730 & Moderate \\
\hline \multirow{5}{*}{4000} & 55 & 62 & 1020 & Moderate \\
\cline { 2 - 5 } & $0(\mathrm{FA}=15 \%)$ & 49 & 2380 & Low \\
\cline { 2 - 5 } & 20 & 55 & 2560 & Moderate \\
\hline \multirow{5}{*}{5000} & 40 & 54 & 1650 & Low \\
\hline & 55 & 40 & 2760 & Low \\
\hline & 0 & 42 & 1790 & Very Low \\
\hline
\end{tabular}

Drying Shrinkage. Length changes of concrete are shown in Fig. 13. For all the concretes with a nominal strength of $21 \mathrm{~N} / \mathrm{mm}^{2}$ and $35 \mathrm{~N} / \mathrm{mm}^{2}$, drying shrinkage strain became equal regardless of GGBFS repalcement. However, in the nominal strength of $28 \mathrm{~N} / \mathrm{mm}^{2}$, drying shrinkage strain of concrete with a GGBFS replacement level of $40 \%$ and $55 \%$ was slightly greater than that of the control concrete . It is said that the drying shrinkage of concrete are affected by replacement level of GGBFS [Japan Cement Association 2011]. In this study, GGBFS replacement did not affect so much because the palpable effect of GGBFS on drying shrinkage were not confirmed.
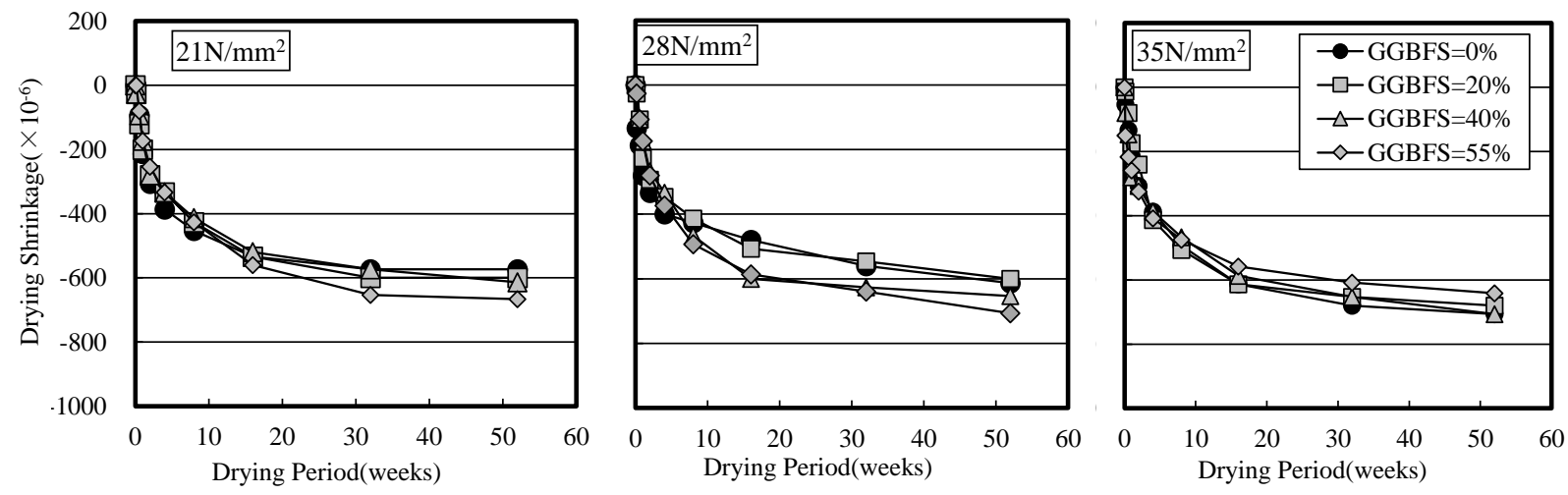

Figure. 13 Drying Shrinkage of Concrete

\section{CARBON DIOXIDE EMISSION FROM BINDER OF CONCRETE}

Calculation Procedure. In order to clarify the effect of carbon dioxide reduction, the specific carbon dioxide consumption of concrete with GGBFS was calculated.

The carbon dioxide emission was assumed to be originated only from binder of concrete. The carbon footprint of concrete binder used for the calculations are shown in Table 11. The value of specific carbon dioxide emission in producing Type $\mathrm{V}$ cement was the averaged value of cement plants in California State in the data of United States Environmental Protection Agency [EPA]. Carbon dioxide emissions from FA and aggregate were not considered in this study because they does not change greatly even cement is replaced with GGBFS. Carbon dioxide emissions of GGBFS were considered only for 
transportation from Japan to California State. Carbon dioxide emissions during shipping were assumed $360 \mathrm{~kg} /$ ton based on document of the Japanese Ministry of the Environment [Japanese Ministry of Environment]. (The carbon dioxide during shipping is $0.04 \mathrm{~kg} / \mathrm{ton}$ and the distance from Japan to California is $9000 \mathrm{~km})$.

Table 11. $\mathrm{CO}_{2}$ Emission by Binders

\begin{tabular}{|c|c|}
\hline & $\mathrm{CO}_{2}$ Emission (kg/ton) \\
\hline Type V & 970 \\
\hline GGBFS & 360 \\
\hline FA & 0 \\
\hline
\end{tabular}

Carbon Dioxide Emission. Carbon dioxide emissions in each concrete are shown in Fig. 15. From this result, emissions of carbon dioxide were reduced with an increase in the replacement amount of GGBFS. Especially, at nominal strength of $21 \mathrm{~N} / \mathrm{mm}^{2}$ and $35 \mathrm{~N} / \mathrm{mm}^{2}$, carbon dioxide emission can be reduced up to $36 \%$, and $29 \%$ at nominal strength of $28 \mathrm{~N} / \mathrm{mm}^{2}$.

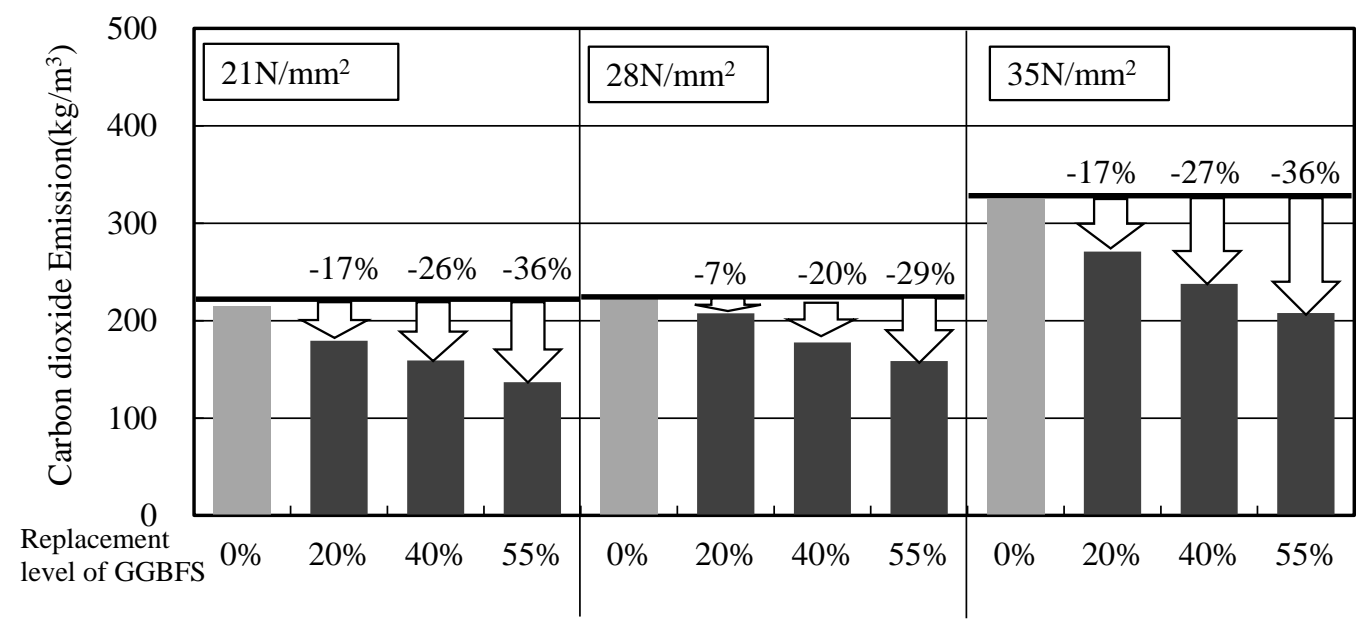

Figure 15. $\mathrm{CO}_{2}$ Emission of Several Proportions

\section{CONCLUSION}

This study reports the concrete properties with GGBFS partially replacing cementr. The following conclusions can be drawn from the obtained experiment data.

- When a part of cement was replaced with GGBFS, slightly larger water-binder ratio could be designed to obtain 28-day compressive strength equivalent to that of control concrete. .

- The sulfate resistance of concrete with GGBFS was equal to that of the control concrete.

- The carbonation speed was faster than that of control concrete when a part of cement was replaced with GGBFS.

- Resistance to chloride ion penetration of concrete was improved when a part of cement was replaced with GGBFS.

- Effect of GGBFS did not affect largely on drying shrinkage because the palpable effect of GGBFS on drying shrinkage were not confirmed.

Focusing only on binder as carbon dioxide source, the emissions of carbon dioxide were reduced with an increase in the replacement ratio of GGBFS. Especially, at nominal strength of $21 \mathrm{~N} / \mathrm{mm}^{2}$ and $35 \mathrm{~N} / \mathrm{mm}^{2}$, carbon dioxide emission can be reduced up to $36 \%$, and $29 \%$ at nominal strength of $28 \mathrm{~N} / \mathrm{mm}^{2}$. 


\section{REFERENCES}

ASTM C 39/C39M. "Standard Test Method for Compressive Strength of Cylindrical Concrete Specimens" ASTM International, West Conshohocken, PA.

ASTM C 143/C 143M. "Standard Test Method for Slump of Hydraulic Cement Concrete" ASTM International, West Conshohocken, PA.

ASTM C 157. "Standard Test Method for Length Change of Hardened Hydraulic-Cement Mortar and Concrete" ASTM International, West Conshohocken, PA.

ASTM C 231. "Standard Test Method for Air Content of Freshly Mixed Concrete by the Pressure Method" ASTM International, West Conshohocken, PA.

ASTM C469/469M. "Standard Test Method for Static Modulus of Elasticity and Poisson's Ratio of Concrete in Compression" ASTM International, West Conshohocken, PA.

ASTM C618. "Standard Specification for Coal Fly Ash and Raw or Calcined Natural Pozzolan for Use in Concrete" ASTM International, West Conshohocken, PA.

ASTM C989/989M. "Standard Specification for Slag Cement for Use in Concrete and Mortars" ASTM International, West Conshohocken, PA.

ASTM C1202. "Standard Test Method for Electrical Indication of Concrete's Ability to Resist Chloride Ion Penetration" ASTM International, West Conshohocken, PA.

JIS A 1153. "Method of Accelerated Carbonation Test for Concrete" Japanese Standard Association.

JSTM C7401. "Method of Test for Chemical Resistance of Concrete in Aggressive Solution" Japan Testing Center for Construction Materials.

EPA. <http://www.arb.ca.gov/cc/ab32/ab32.htm> (Dec. 1. 2015)

EPA. " $\mathrm{CO}_{2}$ Emissions Profile of the U.S. Cement Industry." Japan Testing Center for Construction Materials.

Japan Cement Association. (2011). "Digest Report of the Technical Committee of Concrete." 37-51

Japanese Ministry of Environment〈http://www.env.go.jp/council/06earth/r062-01/>.

Yeau, K. Y. and Kim, E. K. (2005). "An Experimental Study on Corrosion Resistance of Concrete with Ground Granulate Blast-Furnace Slag." Cement and Concrete Research, 35(7), 1391-1399.

Arai, Y. (1984). “Cement Chemistry.” Dai Nippon Tosho, 131-137 